\title{
Intensity of Farmland Cultivated and Soil Bulk Density in Different Physiographic Units In Nyakach District
}

\author{
Authors Names: ${ }^{1}$ Mr. Maurice Kodiwo; ${ }^{2}$ Prof. Boniface Oindo; \\ ${ }^{3}$ Prof. Francis Ang'awa \\ Authors Affiliations: ${ }^{1}$ Jaramogi Oginga Odinga University; web $:^{2}$ Maseno University; web ${ }^{3}$ Jaramogi Oginga \\ Odinga University; KENYA
}

\begin{abstract}
A number of scholars agree that frequent cultivation raises soil bulk density through compaction and destruction of soil structure. However, no research has been conducted to establish how the intensity of farmland cultivatedvaries with soil bulk density in different physiographic units. High soil bulk density lowers root penetration and seed germination and therefore can be used as a measure of land degradation.Likewise the intensity of farmland cultivated can be used to measure agricultural land use intensity. This study focused on establishing the effect of physiographic units on the relationship between the intensity of farmland cultivated and soil bulk densityin Nyakach District of Kenya.Physiographic units considered comprised of Plateau, Scarp Slopes, Plains and Valley Bottoms.A cross-sectional research design involving the use of purposive and simple random sampling was adopted. Structured questionnaire was used to interview 384out of the 29,214farmsteads. Soil samples were collected for laboratory analysis of soil bulk density. Correlation and regression analyses were employed in the assessment of the nature and strength of the relationship between the intensity of farmland cultivated and soil bulk density in different physiographic units. Statistically significant relationships between the intensity of farmland cultivated and soil bulk density were found in the Plateau $(r=-0.267)$, the Scarp Slopes $(r=-0.279)$, and the Valley Bottoms $(r=-0.286)$ at 0.01 level of confidence. The results for the Plains showed that the relationship was statistically insignificant $(r=-0.235)$.The study concluded that physiographic units have a significant influence on the relationships between the intensity of farmland cultivated and soil bulk density.
\end{abstract}

Key words: Physiographic effects; Intensity; Farmland cultivated; Soil bulk density.

\section{Introduction}

Intensity of farmland cultivated is the ratio (or the proportion) of cropped area to total area of the farm. It measures agricultural land use intensity. Soil bulk density is the ratio of the mass of oven-dry soil to its volume. It measures land degradation.

Researches have been conducted globally to establish the relationship between land degradation and agricultural land use intensity (Nagle \& Guinness, 2011; Knox \& Marston, 2009; Giller, 2009; Tilman, 2009; Block, 2008;Leeet al, 2004; and Bentonet al, 2003found a positive correlation).These scholars arepositive correlation theorists. FAO (2012) and Scherr (2007) have found a negative association between land degradation and agricultural land use intensity. This group of scholars isnegative correlation theorists. The current study views these two contrasting schools of thought as a source for further research as well as an option for a third distinct school of thought which may be referred to as the zero correlation theory. Harms et al.(1987) note that there are different effects of agricultural intensification in various types of landscapes.

Methods used to assess land degradation in other countries don't assess land degradation from the context of agricultural land use intensity. Studies focusing on the relationship between land degradation and agricultural land use intensity in Africa have yielded contrasting results. Whereas Tukuret al. (2004), Ogunleyeet al. (2004) and Okikeet al. (2001)found a positive correlation; Matsa\&Muringania (2011) found a negative correlation. These studies do not consider the relationship betweensoil bulk density and the intensity of farmland cultivated in the context of different physiographic units.

Some studies conducted in Kenya also confirm significant relationships between land degradation and agricultural land use intensity. While Hakansson (1989) found a significant positive correlation, Tiffenet al. (1994) found a negative correlation. Currently no study has been conducted in Nyakach to ascertain the relationship between agricultural land use intensity and land degradation using the intensity of farmland cultivated and soil bulk density. Therefore, the objective of this study was to establish the effect of physiographic units on the relationship between the intensity of farmland cultivated and soil bulk density in Nyakach District of Kenya. 


\section{Literature Review}

Phillips-Howard \&Lyon (1994),Dayal (1978) and Leong \& Morgan (1972) used the proportions of farmland cultivated in their various studies to measure agricultural land use intensity. Yimer et al. (2008), Nyamadzawo et al. (2007), Karkee (2004),Celik (2004)), and Mulugeta (2004) observe that high soil bulk density is common in soils with low activity clays and organic matter content which are prone to compaction and hard setting. White (1997) gives bulk density values ranging from less than $1 \mathrm{gcm}^{-3}$ for soils with high organic matter content, 1.0 to $1.46 \mathrm{gcm}^{-3}$ for wellaggregated loamy soils and 1.2 to $1.8 \mathrm{gcm}^{-3}$ for sands and compacted clay soils. He notes that bulk density decreaseswhen mineral soils become finer in texture. Houston et al. (2010) opine that soils with massive structures and less porosity show higher bulk densities ranging from 1.6 to $1.7 \mathrm{gcm}^{-3}$. They argue that bulk densities ranging from 1.0 to $2.0 \mathrm{gcm}^{-3}$ are found in most soils. Jiao et al. (2011) found out that pasture areas had lower soil bulk density than cultivated areas. They attribute this to soil management skills and note that pasture areas have minimal damage to soil structure. Cultivated areas suffered compaction and hence deterioration in soil structure. Li and Shao (2003) and Wakene (2001) state that soil bulk density in freshly tilled farm is lower than in frequently tilled farm. Wakene reports that bulk density is higher in abandoned and lands left fallow for long periods. Tilahun (2007) and Jiao et al. (2011) found no significant effect of land use on soil bulk density. Tilahun obtained $1.41 \mathrm{gcm}^{-3}$ in grazing land, $1.39 \mathrm{gcm}^{-3}$ in cultivated land and $1.35 \mathrm{gcm}^{-3}$ in forest land while Jiao etal. obtained $1.28 \mathrm{gcm}^{-3}$ in farmland, $1.24 \mathrm{gcm}^{-3}$ in artificial grassland, $1.27 \mathrm{gcm}^{-3}$ in natural grassland, $1.32 \mathrm{gcm}^{-3}$ in woodland, and $1.35 \mathrm{gcm}^{-3}$ in shrubland. Dent and Bai (2008) found no obvious relationship between land degradation and individual soil attributes, but recommendedmore rigorous analyses.

Archer \& Smith (1972) found that moisture content increases as bulk density decreases due to increasing volume of pores while air capacity decreases as bulk density increases. Hanks \& Thorp (1956) report that as soil compaction increase, oxygen diffusion rate decrease, crust strength increase and hence seedling emergence is hampered. Soman et al. (1992), Maiti et al. (1986), and Venkaiah (1985) report negative consequences of increasing soil bulk density on agricultural land use intensity. Reviewed literature confirms that intensive cultivation results in reduction of total porosity and hence increased bulk density.

\section{Study area}

\section{Method}

Nyakach District lies within longitudes $34^{\circ} 45^{\prime} \mathrm{E}$ to $35^{\circ} 21^{\prime}$ ' E and latitudes $0^{\circ} 00^{\prime} \mathrm{S}$ to $0^{\circ} 25^{\prime} \mathrm{S}$ with a total land area of $358.6 \mathrm{~km}^{2}$. It falls within Lake Victoria Lowlands and Floodplains Region. Four topographical land formations are the Plateau, Plains, Scarp Slopes and Valley Bottoms. Agricultural land falls into four categories on the basis of relief namely Plateaus - high level regions situated on top of Nyabondo Plateau; Land on slopes - situated on the escarpments surrounding Nyabondo Plateau; Plains - situated in lower part and encompassing river valleys plus the lakeshore; and Valley bottoms - situated along rivers Nyando, Awach-Kano and SonduMiriu where silt and clay brought by surface run-off are deposited. The area has two extreme climatic conditions - floods and droughts. The main economic activity which issubsistence agriculture contributes $52 \%$ of the household incomes.Agro-pastoral land uses include rain-fed smallholder mixed farming and small scale irrigation. Figure 1 below shows the location of Nyakach District in Kenya while Figure 2 shows the map of Nyakach District.

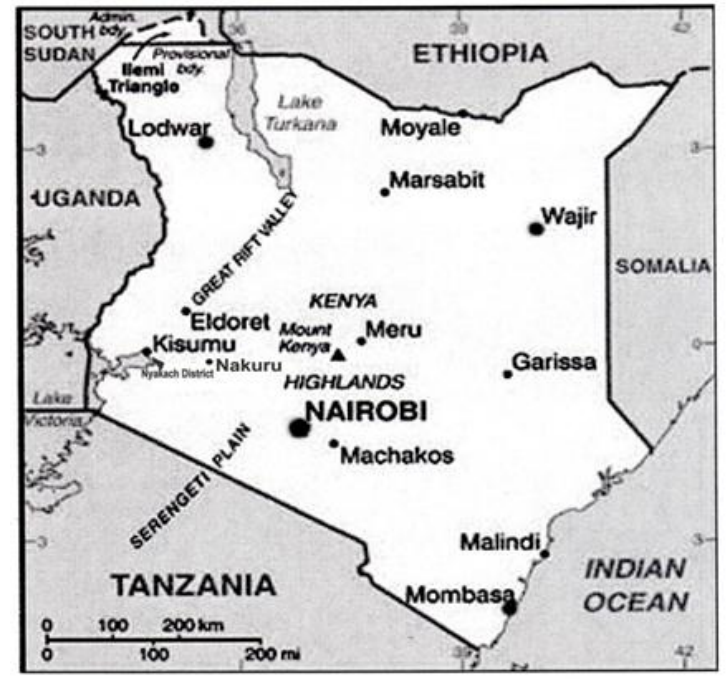

FIG.1: Location of Nyakach in Kenya

Source: Nyakach District Development Office 


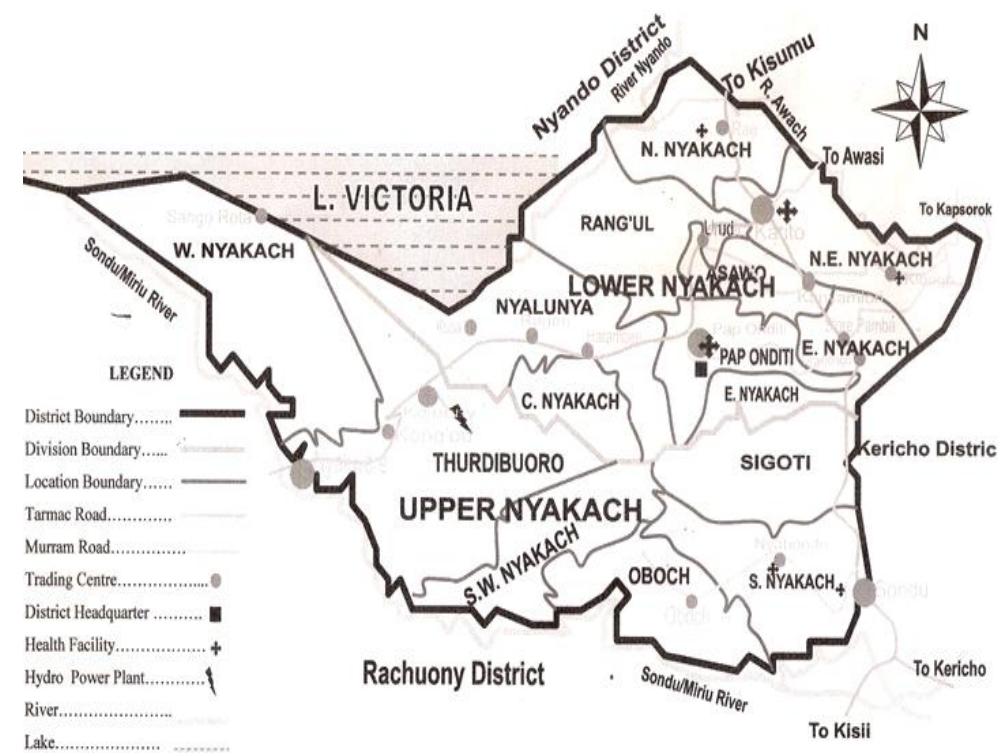

FIG. 2: Map of Nyakach District

Source: Nyakach District Development Office

\section{Study population,Sampling and Data collection}

A sample size of 384 out of a study population of 29,214 farmsteads was selected for the study. Ninety six farmsteads were randomly chosen from each of the four physiographic units using a list of farmers and computer generated table of random numbers. Data was collected from field surveys using a questionnaire and soil samples. Secondary data came from existing relevant documentation. Soil samples were collected using Oring metal cylinder. Fifteen cores taken from different points in each farmstead were bulked and sub-sampled to get a representative soil sample.Labels showed farmstead random number, physiographic unit, and sampling date.

\section{Data analysis and Results presentation}

Frequency tables, measures of central tendency and dispersion were used to inspect the data which was then put on computer coding sheets. Soil samples were dried in air before grinding and sieving to obtain 'Less than $2 \mathrm{~mm}$ air-dry sample' from which a small homogenized subsample was taken for analysis. The subsample was weighed before and after drying in an oven at $105^{\circ} \mathrm{C}$. The dry bulk density was calculated as mass of ovendry soil to volume. The proportion of farmland cultivated was given as the ratio of cropped area to total area. Statistical Package for Social Sciences software version 20 was used for analysis. Correlation coefficient was used to determine the relationship between the two variables.

\section{Results And Discussion}

A weak negative correlation was found between the intensity of farmland cultivated and soil bulk density in all the four physiographic units, namely the Plateau, the Scarp Slopes, the Plains and the Valley Bottoms. The results are summarized in Table1 and Figure 3 below.

TABLE 1: Relationship between Proportions of Farmland Cultivated (POFC) and Soil Bulk Density (SOBD)

\begin{tabular}{|l|l|l|l|l|}
\hline & Plateau & $\begin{array}{l}\text { Scarp } \\
\text { Slopes }\end{array}$ & Plains & $\begin{array}{l}\text { Valley } \\
\text { Bottoms }\end{array}$ \\
\hline Mean SOBD & 1.1354 & 2.1521 & 2.1958 & 1.1542 \\
\hline Mean POFC & 79.1154 & 61.2761 & 67.127 & 74.849 \\
\hline Pearson Correlation & -0.267 & -0.279 & -0.235 & -0.286 \\
\hline Coefficient of Determination & 0.071 & 0.078 & 0.055 & 0.082 \\
\hline Adjusted R-Square & 0.062 & 0.068 & 0.045 & 0.072 \\
\hline Standard Error of Estimates & 0.20271 & 0.31288 & 0.30036 & 0.23388 \\
\hline Calculated F ratio value & 7.23 & 7.94 & 5.518 & 8.349 \\
\hline Critical F ratio value & 6.91 & 6.91 & 6.91 & 6.91 \\
\hline Significance Level & 0.01 & 0.01 & 0.01 & 0.01 \\
\hline
\end{tabular}

Source: Field Data 
Table 1 reveals that both the Plateau and the Valley Bottoms had soil bulk density values less than 1.2, whereas the Scarp Slopes and the Plains had values which were above the critical value of $2.0 \mathrm{gcm}^{-3}$. The negative correlation implies that as the proportions of farmland cultivated increased the soil bulk density decreased. Table 1 also indicates that the coefficients of determination were 0.071 for the Plateau, 0.078 for the Scarp Slopes, 0.055 for the Plains, and 0.082 for the Valley Bottoms. These values mean that the variations in soil bulk density accounted for by changes in the proportions of farmland cultivated were $7.1 \%$ for the Plateau, $7.8 \%$ for the Scarp Slopes, $5.5 \%$ for the Plains, and $8.2 \%$ for the Valley Bottoms. The adjusted $\mathrm{R}^{2}$ values on Table 1 imply that the variance in soil bulk density explained by variations in the proportions of farmland cultivated were $6.2 \%$ for the Plateau, $6.8 \%$ for the Scarp Slopes, $4.5 \%$ for the Plains, and $7.2 \%$ for the Valley Bottoms.

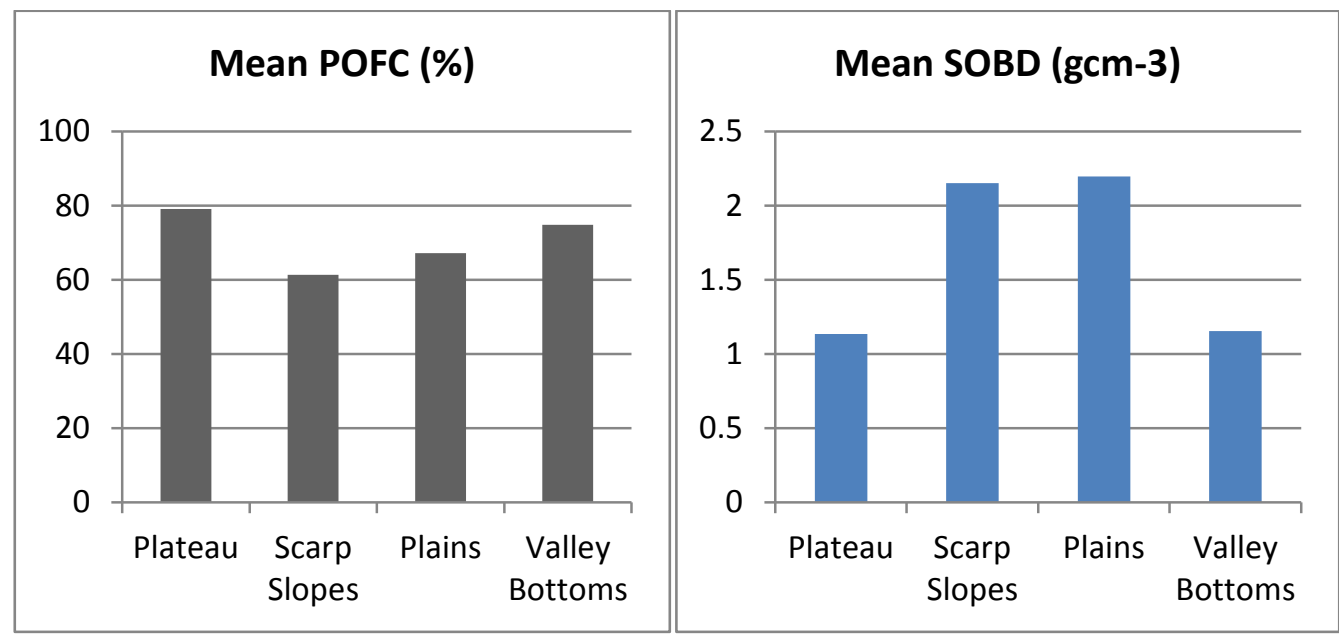

FIGURE 3: Charts for Intensity of Farmland Cultivated (POFC) and Soil Bulk Density (SOBD)

Figure 3 reveals that short mean POFC bars for the Scarp Slopes and the Plains correspond to tall mean SOBD bars for the Scarp Slopes and the Plains. The illustration confirms the negative correlation.

Standard error of estimates given in Table 1 as 0.20271 for the Plateau, 0.31288 for the Scarp Slopes, 0.30036 for the Plains, and 0.23388 for the Valley Bottoms demonstrate that most of the observed values clustered closely to the respective regression lines. This suggests that the regression lines obtained were fairly accurate fits. The linear regression models for each physiographic unit are given in Table 2 below.

TABLE2: Linear Regression Models for Intensity of Farmland Cultivated (POFC) and Soil Bulk Density

\begin{tabular}{|l|l|}
\hline Physiographic Unit & Linear Regression Model \\
\hline Plateau & $\mathrm{y}=1.492+-0.004507 \mathrm{x}$ \\
\hline Scarp Slopes & $\mathrm{y}=2.61467+-0.007549 \mathrm{x}$ \\
\hline Plains & $\mathrm{y}=2.51995+-0.004826 \mathrm{x}$ \\
\hline Valley Bottoms & $\mathrm{y}=1.5796+-0.005684 \mathrm{x}$ \\
\hline
\end{tabular}

Source: Field Data

The implication of the regression models shown in Table 2 is that when all the other factors were held constant, a change of $-0.004507,-0.007549,-0.00482$, and -0.005684 in the proportions of farmland cultivated produced a change of 1.492, 2.61467, 2.51995 1, and 1.5796 in soil bulk density in the Plateau, the Scarp Slopes, the Plains and the Valley Bottoms respectively.

Null hypotheses were formulated to test statistical significance of the linear regression models for each physiographic unit. Null Hypothesis for the Plateau: The linear regression model showing the relationship between the proportions of farmland cultivated and soil bulk density in the Plateau is not statistically significant. According to Table 1 calculated $\mathrm{F}$ ratio value of 7.23 was greater than the critical $\mathrm{F}$ ratio value of 6.91 at 0.01 confidence level. The null hypothesis was therefore rejected. The linear regression model showing the relationship between the proportions of farmland cultivated and soil bulk density in the Plateau was thus found to be statistically significant.

Null hypothesis for the Scarp Slopes: The linear regression model showing the relationship between the proportions of farmland cultivated and soil bulk density in the Scarp Slopes is not statistically significant. Calculated $\mathrm{F}$ ratio of 7.94 shown in Table 1 was greater than the critical $\mathrm{F}$ ratio value of 6.91 at 0.01 confidence 
level. The null hypothesis was thus rejected hence the linear regression model showing the relationship between the proportions of farmland cultivated and soil bulk density in the Scarp Slopes was statistically significant.

Null hypothesis for the Plains: The linear regression model showing the relationship between the proportions of farmland cultivated and soil bulk density in the Plains is not statistically significant. A calculated $\mathrm{F}$ ratio value of 5.518 shown in Table 1 was found to be less than the critical $\mathrm{F}$ ratio value of 6.91 at 0.01 confidence level. The null hypothesis was accepted at $99 \%$ confidence level. The linear regression model showing the relationship between the proportions of farmland cultivated and soil bulk density in the Plains was not statistically significant.

Null hypothesis for the Valley Bottoms: The linear regression model showing the relationship between the proportions of farmland cultivated and soil bulk density in the Valley Bottoms is not statistically significant. Because the calculated $\mathrm{F}$ ratio value of 8.349 shown in Table 1 was greater than the critical $\mathrm{F}$ ratio value of 6.91 at 0.01 confidence level, the null hypothesis was rejected at $99 \%$ confidence level. The linear regression model showing the relationship between the proportions of farmland cultivated and soil bulk density in the Valley Bottoms was statistically significant. These findings are discussed in the paragraphs that follow.

The proportions of farmland cultivated were high in all the four physiographic units due to increasing population and hence escalating demand for more food. This expansion in population in turn led to the reduction in soil bulk density as constant cultivation loosened soil particles, improved aeration, and enhanced bacterial activities. This is supported by Wakene (2001). The negative Pearson correlation values obtained mean that soil bulk density decreased with increase in the proportions of farmland cultivated. A relatively weak but significant negative correlation existed between the proportions of farmland cultivated and soil bulk density except in the Plains. Such a weak correlation was also found by Salchow and Lal (2001) in their study.

Although Dent and Bai (2008) in their study in Kenya did not find any obvious relationship between land degradation and individual soils attributes, this lack of obvious relationship may be partly due to the fact that physical soil quality indicators such as bulk density vary temporally. However, if the proportions of farmland cultivated and soil bulk density are used as surrogates for agricultural land use intensity and land degradation respectively, the findings of this study are in agreement with FAO (2012), Scherr (2007), and Tiffen et al. (1994) who recorded negative correlation. Ofomata (2001) records that intensively cultivated areas exhibit fairly low soil bulk density. The percentage of the variations in soil bulk density explained by the proportions of farmland cultivated was fairly low in all the four physiographic units. This means that the remaining per cent unaccounted for by changes in the proportions of farmland cultivated could have been explained by other variables that were not considered in this study.

\section{Conclusion}

Results revealed that the relationship between the intensity of farmland cultivated and soil bulk density was statistically significant in all the physiographic regions except in the Plains. However, the intensity of farmland cultivated had influenced soil bulk density to a low extent, accounting for between 5.5 to 8.2 per cent of the variations in soil bulk density. Whereas soil bulk density and the intensity of farmland cultivated may not be suitable to study land degradation and agricultural land use intensity in the Plains, they can be successfully applied in the Plateau and Valley Bottoms with two-third probability of success. In the Scarp Slopes they can be used with one-third probability of success.

\section{Acknowledgements}

The authors would like to most sincerely thank all the farmers in Nyakach District who provided data during the field survey. We are equally grateful to District Commissioner, District Development Officer, District Livestock Officer, and District Agricultural officer all of Nyakach District.

\section{References}

[1]. Archer, J. R.\&Smith, P. D.(1972)The relation between bulk density, available water capacity and air capacity of soils. Journal of Soil Science; Vol. 23 (4), pp.475-480

[2]. Benton, T.G., Vickery, J.A. \& Wilson, J.D. (2003) Farmland Biodiversity: Is Habitat Heterogeneity the Key? Trends in Ecology and Evolution, 18, pp.182-188.

[3]. Block, B. (2008) Land Degradation Worse than Previously Reported. World watch Institute.

[4]. Celik, I. (2004) Land-use effects on organic matter and physical properties of soil in a southern Mediterranean highland of Turkey. Soil and Tillage Research, Vol. 83, pp. 270-277.

[5]. Dayal, E. (1978) A Measure of Cropping Intensity.The Professional Geographer, XXX[3], pp. $289-296$

[6]. Dent, D.L. \& Bai, Z.G. (2008) Assessment of Land Degradation Using NASA GIMMS: A Case Study in Kenya. GLADA Report ISRIC - World Soil Information, Wageningen.Available from http://www.globalsoilmap.net.Accessed October 22, 2012.

[7]. FAO (2012) Bagar Farming (Baluwakhati) in river banks of Nepal. Available from teca.fao.org/es/read/7376. Accessed November 24,2012

[8]. Giller, P. (ed.) (2009) How landscape structure, land-use intensity and habitat diversity affect components of total anthropod diversity in agricultural landscapes.Journal of Applied Ecology, 44[2], pp. 340-351.

[9]. Hakansson, N.T. (1989) Social and Political Aspects of Intensive Agriculture in East Africa.Azania, 24, pp. 12-20. 
[10]. Hanks R.J.\&Thorp F.C.(1956) Seedling emergence of wheat asrelated to soil moisture content, bulk density, oxygendiffusion rate and crust strength. Soil Science Society of American proceedings Vol. 20, pp.301 to 310

[11]. Harms, W.B., Stortelder, A.H.F. \&Vos, W. (1987) Effects of Intensification of Agriculture on Nature and Landscape in the Netherlands. In: Wolman, M.G. \& Fournier, F.G.A. (eds.) Land Transformation in Agriculture. SCOPE, John Wiley \& Sons Ltd

[12]. Houston, A., Tranter, G. \& Miller, I. (2010) Bulk Density. Available from: www.usyd.edu.au/agric/web04/Bulkdensitythefinal.htm

[13]. Jiao, F., Wen, Z.M. \&An, S.S. (2011) Changes in soil properties across a chronosequence of vegetation restoration on the Loess Plateau of China. Catena Vol. 86(2011), pp. 110-116.

[14]. Karkee, K. (2004) Land Degradation in Nepal: A Menace to Economy and Ecosystems.

[15]. International Master's Programme in Environmental Science (LUMES) Lund University, Sweden.Available from www.thinkgeography.org.uk/.Accessed March $17^{\text {th }}, 2013$.

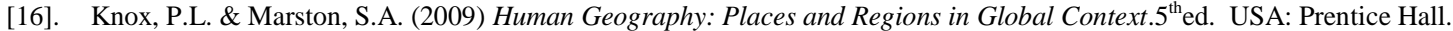

[17]. Lee, R.E., Arthur, W.B., Kelley, A.C. et al. (eds.) (2004) Population, Food, and Rural Development.Oxford: Clarendon Press.

[18]. Leong, O. G. \&Morgan, G. C. (1972) Human and Economic Geography. London:Oxford University Press.

[19]. Li, Y.Y. \& Shao, M.A.(2003)Impact of tillage on water transformation and runoff-sediment-yielding characteristics on slope land.Trans. CSAE Vol. 19(1) pp. 46-50.

[20]. Maiti, R. K., Raju, P.S.\&Peacock, J.M.(1986) Effect of soilcrusting on seedling emergence in sorghum genotypes.International Journal of Tropical Agriculture Vol.IV(1) pp. 15-22.

[21]. Matsa, M.\& Muringaniza, K. (2011)An Assessment of the Land Use and Land Cover Changes in Shurugwi District, Midlands Province, Zimbabwe. Ethiopian Journal of Environmental Studies and Management, 4[2], pp. 1-8.

[22]. Mulugeta, L. (2004) Effects of land use changes on soil quality and native flora degradation and highlands of Ethiopia. Available from: $\quad$ http://pub.epsilon.slu.se/560/1/Silvestria.306.pdf

restoration in the

[23]. Nagle, G. \& Guinness P. (2011) Geography. London: Hodder Education

[24]. Nyamadzawo, G., Chikowo, R., Nyamugafata, P. \& Guller, K.E. (2007) Improved legume tree fallows and tillage effects on structural stability and infiltration rates of kaolinitic sandy soil from central Zimbabwe. Soil Tillage Research, Vol. 96, pp. 182-194

[25]. Ofomata, G. E. K. (2001). Geographic Thought. Enugu: Jamoe Enterprises.

[26]. Ogunleye, A.J., Adeola, A.O., Ojo, L.O. et al. (2004) Impact of Farming Activities on Vegetation in Olokemeji Forest Reserve, Nigeria. Available fromwww.gnest.org/journal/vol6_No2/Ogunleye9620131-140.pdf.Accessed February $20,2013$.

[27]. Okike, I., Jabbar, M.A., Manyong, V.et al. (2001) Agricultural Intensification and Efficiency in the West African Savannas: Evidence from Northern Nigeria. Nairobi: ILRI.

[28]. Phillips-Howard,K.D.\& Lyon, F.(1994) Agricultural Intensification and the Threat to Soil Fertility in Africa: Evidence from the Jos Plateau, Nigeria.The Geographical Journal,160, pp. 252-265.

[29]. Salchow, E. \& Lal, R. (2001) Relating Crop Yields to Physiographic Attributes in Ohio Through Principal Component Analysis: In Stott, D.E., Mohtar, R.H. \& Steinhardt (Eds), Sustaining the Global Farm. Selected papers from the $10^{\text {th }}$ International Soil Conservation organization Meeting published by International Soil Conservation Organization. Available from: http://topsoil.nserl.purdue.edu/destott/default.htm. Accessed April 20, 2013.

[30]. Scherr, S.J. (2007) Soil Degradation: A Threat to Developing Country Food Security by 2020. International Food Policy Research Institute - Food, Agriculture and the EnvironmentDiscussion Paper, 27.

[31]. Soman, P., Jayachandran, R.\&Peacock, J.M.(1992)Effect of soilcrusting on seedling growth in sorghum lines.Experimental Agriculture Vol.28pp. 49-55

[32]. Tiffen, M., Mortimore, M. \& Gichuki, F. (1994) More People, Less Erosion: Environmental Recovery in Kenya.Chischester: Wiley.

[33]. Tilahun, G. (2007) Soil Fertility Status as influenced by different Land Uses in Maybar Areas of South Wello Zone, North Ethiopia. M.Sc. Thesis, Haramaya University.

[34]. Tilman, D. (2009) Global environmental impacts of agricultural expansion: The need for sustainable and efficient practices. The Proceedings of the National Academy of Sciences of the United State of America.

[35]. Tukur, A.L., Bashir, B.A. \& Mubi, A.M. (2004) Agricultural Land Use and Land Degradation in Adamawa State. Global Journal of Environmental Science, 3[1],pp. 27-31.

[36]. Venkaiah, K.(1985)Effect of bulk density on growth and yield ofgroundnut.Indian Journal of Agronomy Vol.30(2)pp. 278-280

[37]. Wakene N.(2001) Assessment of important physicochemical properties of dystric udalf (dystric

Nitosols) under different management system in Bako area, Western Ethiopia; M.Sc. Ethiopia.

[38]. White, R.E. (1997) Principles and Practices of Soil Science: The Soil as a Natural Resource.4Ed., USA, Blackwell Publishing Co.

[39]. Yimer, F., Messing, L., Ledin, S. \& Abdelkadir, A. (2008) Effects of different land use types on infiltration capacity in a catchment in the highlands of Ethiopia. Soil Use and Management, Vol. 24, pp. 344-349 